\title{
Damage Intensity in Relation to Fruit Fly Incidence in Guava (Psidium guajava L.) in Orchards of Eastern India
}

\author{
B. R. Jana ${ }^{1 *}$ and Md. Idris ${ }^{2}$ \\ ${ }^{1}$ ICAR-RCER, Research Centre Ranchi, Jharkhand, -846005, India \\ ${ }^{2}$ ICAR -Research Complex for Eastern Region, Patna-800014, India \\ *Corresponding author
}

\begin{tabular}{|l|}
\hline K e y w o r d s \\
$\begin{array}{l}\text { Fruit flies, guava } \\
\text { crop loss, methyl } \\
\text { eugenol trapping, } \\
\text { Bactrocera sp. }\end{array}$ \\
\hline Article Info \\
\hline $\begin{array}{l}\text { Accepted: } \\
\text { 25 February } 2020 \\
\text { Available Online: } \\
\text { 10 March } 2020\end{array}$ \\
\hline
\end{tabular}

A B S T R A C T

Incidence of fruit fly and damage intensity in guava (Psidium guajava L.) in orchards of eastern India, Ranchi, were studied during rainy and winter season in 2013 and 2014 under ICAR-RCER. The observations were recorded on number of flowers and fruits /plant, which indicated that flowers and fruits were higher in number during rainy season. However, the weights of fruits were higher in winter season as compared to rainy. The number of fruits drop were recorded higher in rainy season about $7.72 \%$ in normal planting (NP) and $8.85 \%$ in high density planting (HDP) during first year study (2013). In second year of study (2014), the damages were of rainy season $7.25 \%$ and $8.49 \%$ in NP and HDP, respectively. The maximum and minimum winter losses (2013) were $7.50 \%$ and $5.02 \%$ in NP and HDP planting, respectively. Furthermore, identification of fruit fly species was studied at Patna and Ranchi during 2014, simultaneously. It has been found that Bactrocera zonata was trapped more $(83.00 \%)$ in rainy season as compared to other species (B. dosalis, B. cucurbitae and B. tau) at ICAR-RCER Patna, India, whereas $B$. correcta was trapped more $(47.25 \%)$ followed by $B$. zonata, $B$. dorsalis and B. cucurbitae in the same season in ICAR-RCER, Ranchi.

\section{Introduction}

In agricultural crops, despite of taking suitable crop protection measures, insect pests yet are responsible for an average of $16-18 \%$ yield losses (Oerke, et al., 1994 and Oerke 2006). The guava (Psidium guajava L.) is one of major fruit crops after mango, banana and citrus grown in the subtropical and tropical region in India. Due to its ease of cultivation and fetching lower prices in India, guava fruit is known as poor man's apple or apple of tropics. The area and production of this crop are 268.2 Th ha and 3667.9 Th MT (NHB Database, 2014) in India. The infestation of different fruit fly species is the major limiting factor in production of rainy season guava. Infestation in the range of 2046 per cent with losses of 16 - 40 per cent is observed in U.P., India (Hasseb, 2007). 
Rainy season fruits are mainly damaged in a range of $30 \%$ through the infestation of guava fruit fly. In USA and in severe case fruit loss reaches up to $3-100 \%$ through Bactrocera zonata. In Pakistan, the losses are about 50$90 \%$. In Ghana, South Africa, losses of fruit and vegetables are about $70 \%$ due to infestation of different species of Bactrocera (GNA, 2016). In guava, $80 \%$ crop loss has been found in India and Pakistan (FAO, 2010). Although detailed studies on crop loss are lacking, the infestation of fruit fly in winter guava is relatively less due to low temperature and dry winter in most parts of the India. In Northern India, guava fruit flies namely; B. zonata, B. dorsalis, B. cucurbitae are the prominent which cause havoc loss on the crop. In South India, B. correcta is one of the important fruit fly of guava and emerging recently as an important insect, which can cause $80 \%$ damage. A reduction in the total phenolic content in fruits of susceptible cultivars also causes damage (Manoukas, 1993; Md. Jalaluddin and Sadakathulla,1999). Dorsalis-zonata-correcta complex are found in southern India in case of mango and guava crops. Population of $B$. correcta in guava orchards when co-occurring with $B$. dorsalis and $B$. zonata has been the cause of concern of major crop loss for the fruit growers of Southern India. Sometimes population is of $80 \%$ higher than those of both the $B$. dorsalis and B. zonata (Kapoor, 2002).

Guava fruit fly, a polyphagus pest, namely; Bactrocera correcta (Bezzi) in India, invades wide variety of fruit crops in Ranchi, Jharkhand and may become prominent in the areas of south-western coastal (Kerala, Karnataka, Tamilnadu, Maharashtra and Gujarat) parts of India by 2050 and 2070 (Choudhary et al., 2019). Hence, in the present study, we estimated the crop loss and identified different fruit fly species with critical observations.

\section{Materials and Methods}

A field trial was conducted to investigate the level of infestation of fruit flies in guava under east India condition, particularly in the state of Jharkhand and Bihar. Survey was conducted to study the per cent infestation of guava of their respective ecological regions like sub- humid sub-tropical region of Ranchi and subtropical hot and humid region of ICAR RCER, Patna in different orchards. In both the locations two each different orchards of guava with the spacing's of $5 \mathrm{~m}$ x $5 \mathrm{~m}$ (NP) and $1 \mathrm{~m} \times 2 \mathrm{~m}$ (HDP) were under study. The no of traps (methyl eugenol) /ha was 12-14. Yield of the orchards and fruit infestation by different fruit flies were calculated. The level of infestation was studied by counting all infested and dropped fruits randomly. The data regarding infestation caused by fruit flies guava were recorded daily in each of the experimental unit. Data were recorded for two consecutive years i.e., 2013 and 2014 from fruit set to maturity. The age of the plants was 4-6 years. The total number of fruits and number of infested fruits were counted and converted into per cent infestation by the following formula.

$$
\text { Fruits infestation }(\%)=\frac{\text { No. of infested fruits }}{\text { Total Number of Fruits }} \times 100
$$

Data were analyzed according to the procedure of appropriate Randomize Block Design (RBD) with four replications. WASP 2.0 (ICAR, India) package was used for analysis of variance for production and yield loss of guava.

For different types of fruit fly species infestation, the significant means were separated with in the column by using least significant difference (LSD) test (Jan et al., 2009). The cultivar for experiment was Lucknow-49. 
Bio-enzyme for source sink relationship (SSR) $3.0 \mathrm{~g}$ was applied to (NP) normal planting for guava cultivation $(5 \mathrm{~m} \times 5 \mathrm{~m}$ spacing) whereas to get maximum yield in both the years, 40-50\% pruning was imposed for high density planting (HDP). However, species identification was done in both Patna and Ranchi station simultaneously during 2014. Treatments were as follows:

\begin{tabular}{|c|c|c|c|}
\hline Treatment & $\begin{array}{l}\text { Planting } \\
\text { Distance }\end{array}$ & $\begin{array}{l}\text { Seasons of } \\
\text { Cultivation }\end{array}$ & Design \\
\hline T1 NP & $5 \mathrm{~m} \times 5 \mathrm{~m}$ & Rainy & RBD \\
\hline T2 NP & $5 \mathrm{~m} \times 5 \mathrm{~m}$ & Winter & RBD \\
\hline T3 HDP & $1 \mathrm{~m} \times 2 \mathrm{~m}$ & Rainy & RBD \\
\hline T4 HDP & $1 \mathrm{~m} \times 2 \mathrm{~m}$ & Winter & RBD \\
\hline
\end{tabular}

\section{Results and Discussion}

A close perusal of the table- 1 revealed that during 2013, the maximum no. of flowers (182.94/plant) and fruits (147.11/plant) were produced by the rainy season crop as compared to winter in normal spacing $(5 \mathrm{~m} \mathrm{x}$ $5 \mathrm{~m})$. The similar trends were also observed by second year regarding rainy crop (table-2). This results were also in corroborated by Menzel and Paxton (1986) regarding total yield in NP orchard and Mehta et al., (2010) in HDP guava crop under sub-humid, subtropical climate of Jharkhand. In both the years' winter fruit weight were the maximum $(>190.0 \mathrm{~g})$. These results were also in conformity with the findings of Jana et al., (2010). In case of high density orcharding (HDP) and during rainy season, the productions were $21.61 \mathrm{t} / \mathrm{ha}$ and $23.31 \mathrm{t} / \mathrm{ha}$ during 2013 and 2014, respectively. The damaged fruits during rainy seasons were $2.097 \mathrm{t} / \mathrm{ha}$ and $2.163 \mathrm{t} / \mathrm{ha}$ during 2013 and 2014, respectively in NP. Regarding loss during rainy season under HDP was $8.85 \%$ in 2013 and $8.49 \%$ in 2014 (Fig-1). These results were in accordance with the findings of Kapoor (2002), in India where they noticed that Bactrocera spp. were major threat to guava cultivation and damaged about $40 \%$ due to these flies. Jalaluddin et al., (1999) recorded $B$. correcta damaging guava fruits to the extent of 60-80 per cent. Hasseb (2007) reported the infestation of fruit fly Bactrocera species to the extent of 20-46 per cent with crop loss of 16-40 per cent in U.P., India. Khanh et al., (2008) observed that the infestation of Bactrocera species to the extent of 4.0 per cent, 16.0 per cent and 94.0 per cent in early season, mid-season and late season, respectively, in 2007, in the North Vietnam.

Table.1 Yield and loss assessment of guava due to fruit fly during 2013 at Ranchi

\begin{tabular}{|c|c|c|c|c|c|c|}
\hline Treatments & $\begin{array}{c}\text { No. of } \\
\text { Flowers/plant }\end{array}$ & $\begin{array}{c}\text { No. of Fruits } \\
\text { /plant }\end{array}$ & $\begin{array}{c}\text { Fruit } \\
\text { Weight(g) }\end{array}$ & Yield (t/ha) & $\begin{array}{c}\text { Fruit Drop } \\
\text { (Fruit Fly) t/ha }\end{array}$ & $\begin{array}{c}\text { Total yields } \\
\text { (t/ha) }\end{array}$ \\
\hline T1 & 182.94 & 147.11 & 151.57 & 8.918 & 0.746 & 9.664 \\
\hline T2 & 72.54 & 68.23 & 195.66 & 5.339 & 0.438 & 5.837 \\
\hline T3 & 42.59 & 33.15 & 130.42 & 21.61 & 2.097 & 23.707 \\
\hline T4 & 30.08 & 24.82 & 190.55 & 23.64 & 1.249 & 24.889 \\
\hline CD at 5\% & $\mathbf{2 . 2 6}$ & $\mathbf{5 . 0 5}$ & $\mathbf{4 . 2 3}$ & $\mathbf{1 . 2 3}$ & $\mathbf{0 . 2 2}$ & $\mathbf{2 . 4 5}$ \\
\hline
\end{tabular}


Table.2 Yield and loss assessment of guava due to fruit fly during 2014 at Ranchi

\begin{tabular}{|c|c|c|c|c|c|c|}
\hline Treatments & $\begin{array}{c}\text { No. of } \\
\text { Flowers/plant }\end{array}$ & $\begin{array}{c}\text { No. of Fruits } \\
\text { /plant }\end{array}$ & $\begin{array}{c}\text { Fruit } \\
\text { Weight(g) }\end{array}$ & $\begin{array}{c}\text { Yield } \\
\text { (t/ha) }\end{array}$ & $\begin{array}{c}\text { Fruit Drop } \\
\text { (Fruit Fly) t/ha }\end{array}$ & Total yields (t/ha) \\
\hline T1 & 204.33 & 154.69 & 152.22 & 9.42 & 0.736 & 10.156 \\
\hline T2 & 83.19 & 72.75 & 196.84 & 5.73 & 0.404 & 6.134 \\
\hline T3 & 47.35 & 35.46 & 131.45 & 23.31 & 2.163 & 25.473 \\
\hline T4 & 31.05 & 25.45 & 192.42 & 24.49 & 0.674 & 25.164 \\
\hline CD at 5\% & $\mathbf{1 5 . 5 3}$ & $\mathbf{9 . 5 2}$ & $\mathbf{1 0 . 9 8}$ & $\mathbf{2 . 9 1}$ & $\mathbf{0 . 3 7}$ & $\mathbf{3 . 2 1}$ \\
\hline
\end{tabular}

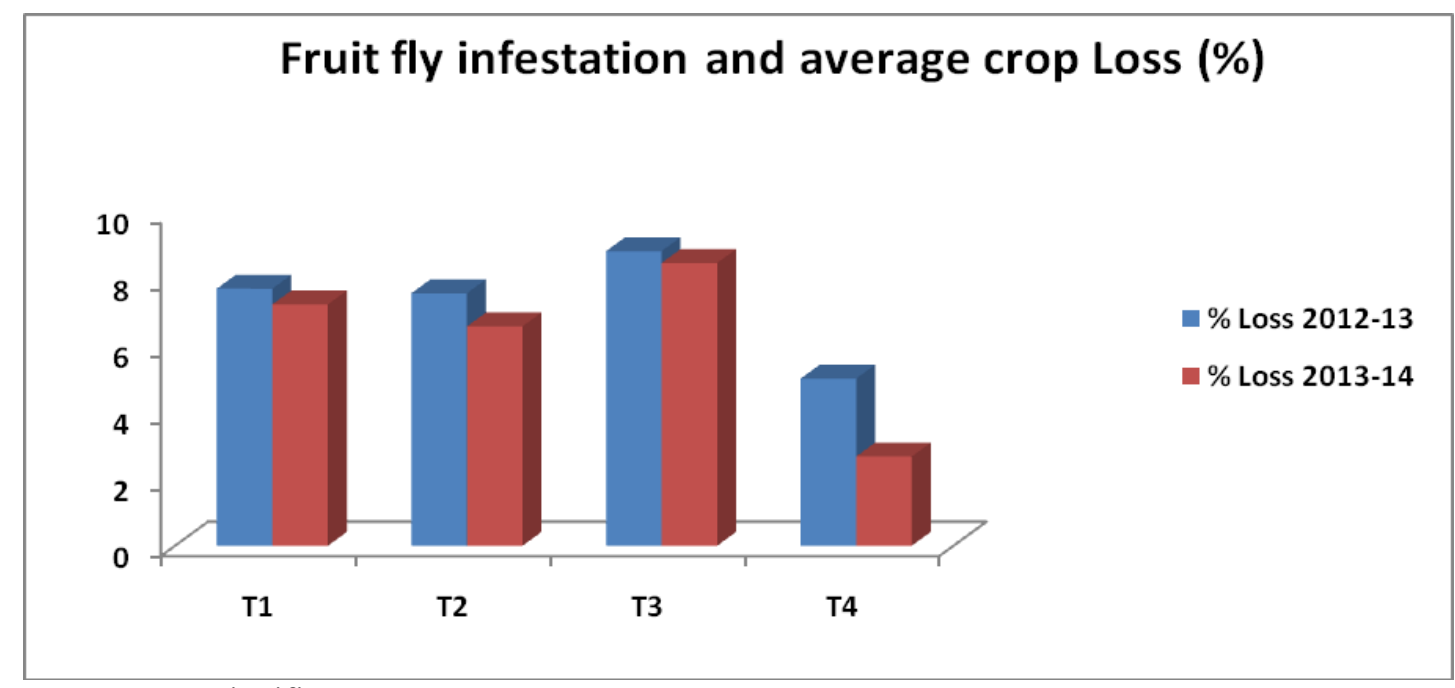

Means were significant at $p$

Fig.1 Estimation of loss \% of guava fruits due to fruit flies during 2012-14

\section{Average no of fruit flies in different seasons and spacings}

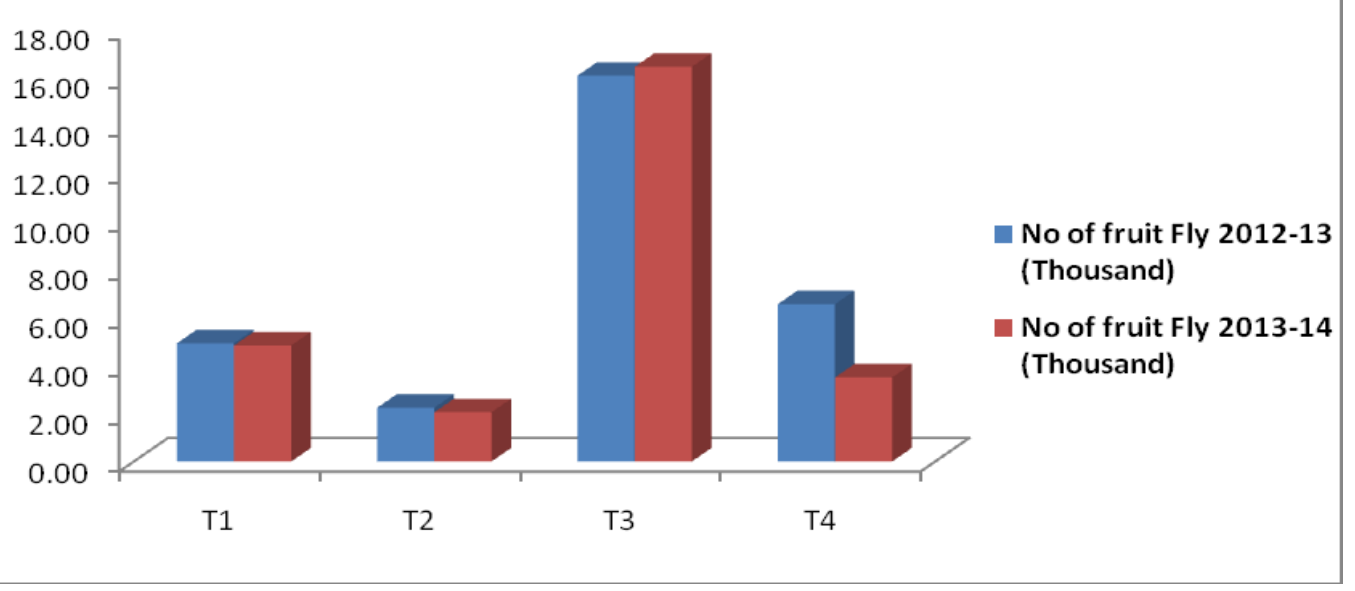

Means were significant at $p>0.05$

Fig.2 Average population of fruit flies at different spacing of guava orchards at Ranchi 


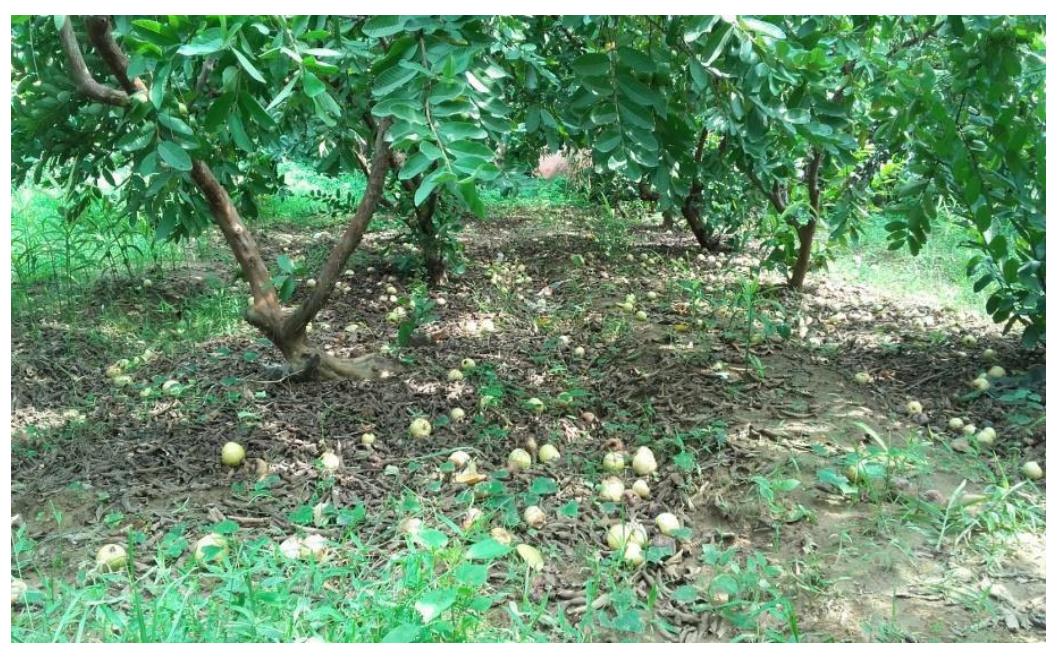

Fig.3 Infected and dropped guava fruits under rainy season in NP (5m x 5m spacing)

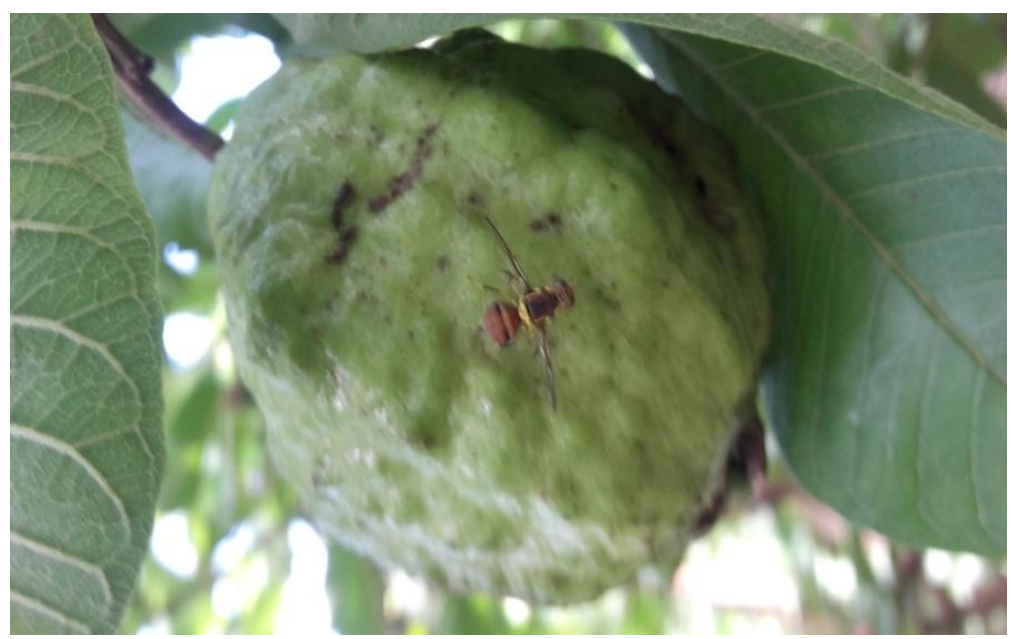

Fig.4 Bractocera zonata on guava fruits

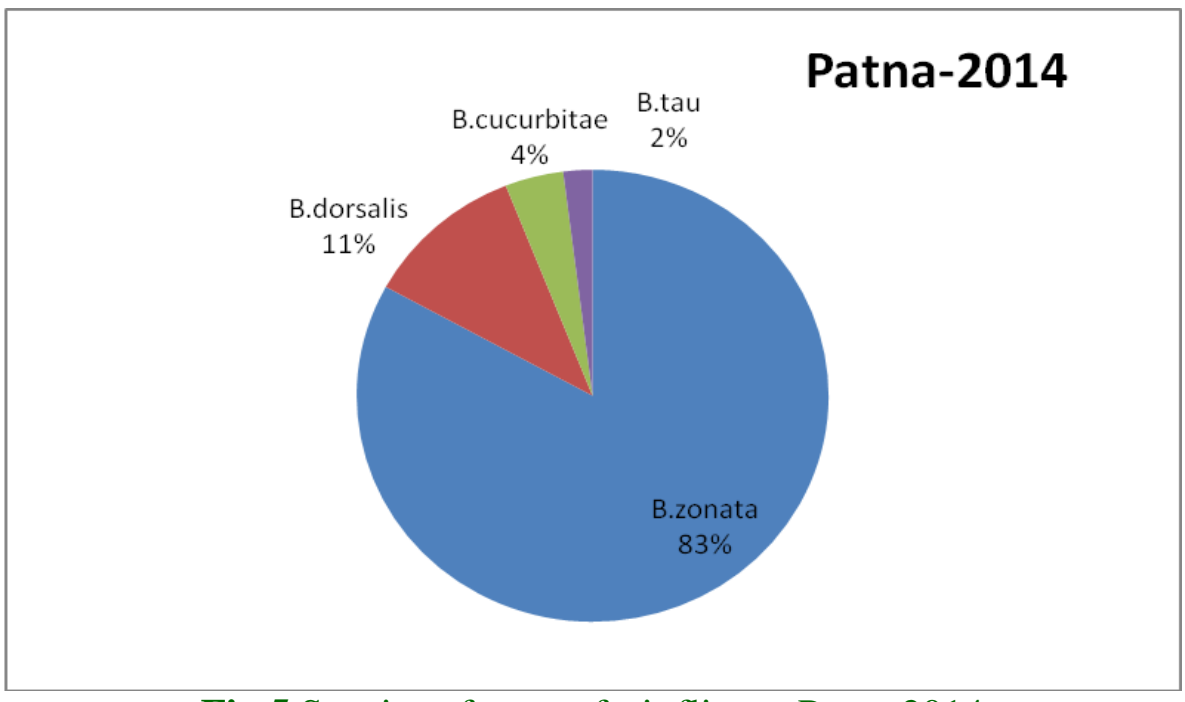

Fig.5 Species of guava fruit flies at Patna 2014 


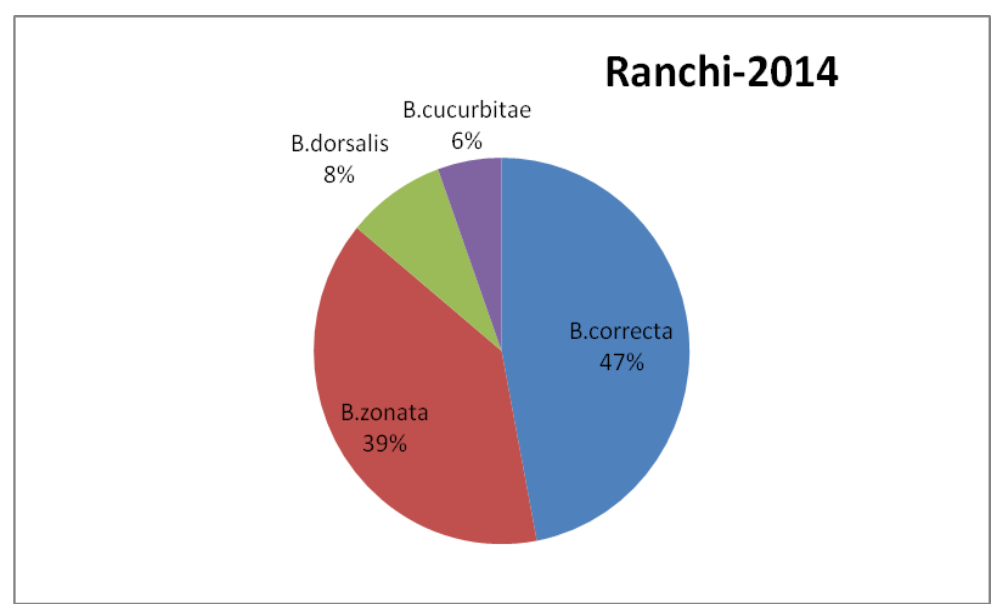

Fig.6 Species of guava fruit flies at Ranchi 2014

In our present study, we found that Bactrocera zonata was major fruit fly which causes havoc losses in Patna whereas $B$. correcta at Ranchi (Fig-5-6). In NP, average loss was $7.72 \%$ in 2013 and $7.25 \%$ in 2014 under Ranchi agro-climatic condition during rainy season. But in case of HDP, the per cent loss was $5.02 \%$ in 2013 and $2.67 \%$ in 2014 in winter season (Fig-1). Similar results regarding damage of guava fruit crops during rainy season were also reported by Kapoor (2002), Haseeb (2007) and Khanh (2008).

From methyl eugenol trapping, different species were identified. These species were B. zonata $(83.0 \%)$ B. dosalis $(11.0 \%)$ B. cucurbitae (4\%) and B. tau (2.0\%), which infested the guava orchards in Patna, India (rainy) (Fig-5). In Ranchi, fruit flies were B. correcta $(47.0 \%)$, B. zonata $(39.0 \%), B$. dorsalis $(8.0 \%)$ and B. cucurbitae $(6.0 \%)$ (rainy). Rajitha and Viraktamath (2006) also reported the infestation of Bactrocera spp. in guava orchards during August and September in Karnataka states of India. Choudhary et al., 2019 also stated that Bactrocera correcta was the most prominent fruit fly for guava in eastern India. From infected fruits and fruit fly traps, the average no. of fruit flies was calculated and it has been observed that under HDP in second year rainy season crop, the total no. of fruit flies was the maximum of 16.45 thousand/ha in the 6 months crop (May to October) (Fig-2). Fig: 3-4 were crop loss view and view of Bactrocera zonata on guava fruit at Patna.

\section{Acknowledgement}

Authors are thankful to Director ICARRCER, Patna, for technical guidance and funding. For supplementary information, authors are also thankful to PI of NICRA project at Ranchi Centre.

\section{References}

Choudhary, J.S., Kumari, M., Malli SS., Dhakar,M. K., Das, Bikash., Singh, A.K. and Bhatt, B.P. 2019. Predicting impact of climate change on habitat suitability of guava fruit fly, Bactrocera correcta (Bezzi) using MaxEnt modeling in India. Journal of Agromet, 21(1) : 24-30.

FAO Reports. 2010. TECA : Crop Protection: Integrated management of fruit flies in India and Pakisthan.

GNA (Ghana News agency). 2016. Fruit flies causing crop losses in Ghana. Source: www. businessghana.com.

Hasseb, M. 2007. Current status of insect pest problems in guava. Acta. Hort. (ISHS), 735: 453-467. 
Jalaluddin, S. Md. and Sadakathulla, S. 1999. Development and survival of Bactrocera correcta (Bezzi) (Diptera : Tephritidae) on selected guava cultivars. Pest Management in Horticultural Ecosystem, 5(1): 24-27.

Jalaluddin, S.M., Natarajan, K., Sadakathulaa, S. and Balasubramaniyam, S. 1999. Discovery of the guava fruit fly Bactrocera correcta (Bezzi). Entomon., 24 (2): 195-196.

Jan, M.T., Shah, P., Hollington, P. A., Khan, M.J. and Sohail, Q. 2009. Agriculture Research: Design and Analysis, A Monograph. NWFP Agricultural University, Peshawar, Pakistan.

Jana, B.R., Munsi, P.S., Manna D.C. and Das, Bikash. 2010. Evaluation of Guava (Psidium guajava L.) Genotypes based on fruit morphology, physico-chemical properties and yield under eastern plateau condition. Indian J. Plant Genet. Resources, 23 (1) : 25-29.

Kapoor, V.C. 2002. Fruit Fly pest and their present status in India. Proceedings of $6^{\text {th }}$ international fruit fly symposium, 6$10^{\text {th }}$ May, 2002, Stellerstosch, South Africa, pp-23-33.

Khanh, L.D., Dao, D.T., Nguyen, T.T.H., Tran, T.T., Vu, T.T.T., Phan, M.T., Vu, V.T. and Dang, D.T. 2008. Fruit flies and their control by using protein bait in Vietnam.
GAP workshop in Binh Thuan, 2122/7/2008.

Manoukas, A.G. 1993. The effect of some phenols on the larval performance of the olive fruit fly Dacus oleae Gmel (Dipt: Tephritidae). Journal of Applied Entomon. (Germany), 116:303-307.

Meheta, S. Singh,S.K., Das, Bikash, Jana, B. R. and Mali SS. 2012. Effect of pruning on guava cv.. Sardar under ultra high density orcharding system. International Journal of Plant Research, 25(2):192195.

Menzel, C. M. and Paxton, B.F. 1986. The Pattern of growth, flowering and fruiting of guava varieties in subtropical Queens land. Australian Journal of Experimental Agriculture, 26(1): DOI: 10.1071/EA9860123.

NHB Data Base. 2014. National Horticulture Board, Gurgaon, New Delhi, India.

Oerke E. 2006. Crop losses to pests. The Journal of Agricultural Science, 144:31-43

Oerke E.C., Dehne, H.W., Schonbeck, F., and Weber, A. 1994. Crop production and protection: Estimated losses in major food and cash crops. Elsevier, Amsterdam.

Rajitha, A.R. and Viraktamath, S. 2006. Monitoring of fruit fly (Diptera: Tephritidae) in guava orchards at Dharwad, Karnataka, Karnataka Journal Agric. Sci., 19(1): 45-49.

\section{How to cite this article:}

Jana B. R. and Md. Idris. 2020. Damage Intensity in Relation to Fruit Fly Incidence in Guava (Psidium guajava L.) in Orchards of Eastern India. Int.J.Curr.Microbiol.App.Sci. 9(03): 30483054. doi: https://doi.org/10.20546/ijcmas.2020.903.349 